\title{
Cytotoxic effects and anti-proliferative cancer activity of coelomic fluid from Lumbricus rubellus promotes apoptosis and reduces G2/M phase progression in HT-29 cells
}

\author{
Sofy Permana ${ }^{1}$, Pearlindah ${ }^{2}$, Zurniatus Sholihah ${ }^{2}$, Agustin Iskandar ${ }^{3,4}$, Hani Susanti ${ }^{4}$, Agustina Tri Endharti ${ }^{3,5^{*}}$ \\ ${ }^{1}$ Departement of Biology, Faculty of Mathematics and Natural Sciences, Brawijaya University, Malang, East Java, Indonesia. \\ ${ }^{2}$ Master Program in Biomedical Science, Faculty of Medicine, Brawijaya University, Malang, East Java, Indonesia. \\ ${ }^{3}$ Department of Parasitology, Faculty of Medicine, Brawijaya University, Malang, East Java, Indonesia. \\ ${ }^{4}$ Department of Clinical Pathology, Faculty of Medicine, Brawijaya University, Malang, East Java, Indonesia. \\ ${ }^{5}$ Biomedical Central Laboratory, Faculty of Medicine, Brawijaya University, Indonesia.
}

\begin{tabular}{|c|c|}
\hline ARTICLE INFO & ABSTRACT \\
\hline ory: & \multirow{5}{*}{$\begin{array}{l}\text { This study has investigated the effect of chemotherapy drugs combined Coelomic Fluid (CF) derived from Lumbricus } \\
\text { rubellus in HT-29 cells. HT-29 cells were treated with a combination of 5-fluorouracil (5-FU) }(5 \mu \mathrm{g} / \mathrm{ml} \text { ) and Coelomic } \\
\text { Fluid Lumbricus (CFL) }(5 \mu \mathrm{g} / \mathrm{ml}, 10 \mu \mathrm{g} / \mathrm{ml} \text {, or } 20 \mu \mathrm{g} / \mathrm{ml}) \text {, respectively. The cells were incubated for } 24 \text { hours and then } \\
\text { analyzed by flow cytometry to assess apoptosis, cell cycle progression, and proliferation. The cytotoxicity effect was } \\
\text { measured by MTT assay that causes } 50 \% \text { decrease in cell viability (IC50 value). Results showed that the percentage of } \\
\text { apoptosis in combined-therapy groups significantly higher than 5-FU single therapy group }(p<0.001) \text {. Additionally, } \\
\text { the percentage of proliferation and cell growth significantly inhibited of } 5 \text {-FU and CFL combination groups }(p< \\
0.001) \text {. However, cell cycle slightly reduced the percentage of G2/M phase. Our results showed that CFL inhibited } \\
\text { cell proliferation that is strictly dependent on colon cancer. These findings suggest that CFL have cytotoxicity effect to } \\
\text { inhibit cell growth, anti-proliferative activity and increased apoptosis against human colon cancer cells. }\end{array}$} \\
\hline 018 & \\
\hline & \\
\hline Available online: $30 / 11 / 2018$ & \\
\hline $\begin{array}{l}\text { Key words: } \\
\text { Apoptosis, cell cycle, cell } \\
\text { proliferation, cytotoxic } \\
\text { effect, coelomic fluid, 5-FU. }\end{array}$ & \\
\hline
\end{tabular}

\section{INTRODUCTION}

Colorectal cancer is the third most common cancer in the world, with 1.4 million cases diagnosed and 694,000 deaths per year. Colorectal cancer accounts for $10 \%$ of the total cancer cases in men $(746,000)$ and $9.2 \%$ of the total cases in women $(614,000)$ (Ferlay et al., 2015). In Indonesia, the rate of incidence of colorectal cancer is $19.1 \%$ for men and $15.6 \%$ for women (Ferlay et al., 2010). Colon cancer is a colonic epithelium disease identified by the loss of control of malignant cell growth, resulting in the invasion of surrounding tissue and other organs (Niederhuber et al., 2014).

The common treatment for colon cancer is surgery, with a high recovery rate at early stages and utilization of radiotherapy

*Corresponding Author

Agustina Tri Endharti, Department of Parasitology, Faculty of Medicine, Brawijaya University, Malang, East Java, Indonesia. E-mail: tinapermana@yahoo.com; tinapermana.fk@ub.ac.id and chemotherapy drugs at advanced stages (Mishra et al., 2013). One therapeutic agent, adjuvant 5-fluorouracil (5-FU), is consumed by patients at high risk in the second or third stage (Watanebe et al., 2015). The active metabolites of 5-FU, fluorodeoxyuridine monophosphate (FdUMP), fluorodeoxyuridine triphosphate (FdUTP), and fluorouridine triphosphate (FTUTP), can inhibit the activity of thymidylate synthase (Chua et al., 2011). However, the therapy presents side-effects such as neutropenia, stomatitis, diarrhea, and cardiotoxicity (Ciccolini et al., 2010). Increasing the activity of 5-FU by combination treatment with natural materials is an important avenue to explore for the treatment of colon cancer. A combination treatment of 5-FU and a natural material could increase the sensitivity of cancer cells by capturing cell cycle mechanisms, inhibiting proliferation, and promoting apoptosis (Redondo-Blanco et al., 2017). Recent epidemiological studies show that herbal treatment improves prognosis in patients with colon cancer; therefore, it is possible to further explore for new 
target therapy in the future (Au-Yeung and Ko et al., 2010).

Earthworms are reported to possess bioactive molecules that can be used as remedies for various diseases, especially cancer (Cooper et al., 2012). Eisenia foetida has coelomic fluid (CF) macromolecules capable of significantly inhibiting the proliferation of HeLa cells and human lung adenocarcinoma cell line LTEP-A2 (Zhang et al., 2011). Administration of CF from Eudrilus eugeniae has shown increased apoptotic activity in SiHa cells, and 85\% cell death in lung cancer cell line A549 and colorectal tumor cell line HTC 116 (Jaabir et al., 2011; Vidya et al., 2016).

Proliferation, cell cycle regulation, and apoptosis are targets for cancer therapy. This study reviews the role of these targets in colon cancer and treatment strategies using various inhibitors. The distinct mechanisms between 5-FU and CFL by combination therapy are expected to enhance the performance of 5-FU in colorectal cancer therapy and improve its therapeutic efficacy.

\section{MATERIALS AND METHODS}

\section{Lumbricus rubellus}

Earthworm was collected from a commercial vermiculture unit CV Rumah Alam Jaya Organik, Malang and maintained in a container containing decomposed organic matter. All experimental procedures were approved by the Ethical Committee Brawijaya University, Malang, Indonesia (No. 299/ EC/KEPK/08/2017).

\section{Preparation of coelomic fluid Lumbricus rubelus}

Earthworm was weighed for 15 grams and washed in distilled water. They were placed in boxes which have filter paper and were transferred to a new box in order to be given heat and cold treatment (Dinesh et al., 2013). Briefly, water in a glass beaker $(10 \mathrm{ml})$ was prepared by heating in an electric water heater with an inserted inside it to measure the temperature between $45-50^{\circ} \mathrm{C}$ was used to give the heat shock. The ice pack prepared and put in plastic was used to give the cold shock. The heat and cold shock treatment were done at 3 minutes and repeated until the earthworm collapse they were given stimulus from beaker glass filled hot water and ice pack in the plastic shifting on the surface of the earthworms' body CFL were released through the back pores of the body due to "heat and cold shock". CFL was collected in a sterile Eppendorf tube using a pipette. The filtrate was stored in aliquots at $-20^{\circ} \mathrm{C}$ for further use. The supernatant measured on nanodrop to see protein levels.

\section{Cell culture and treatment}

HT-29 cell line was obtained from American Type Culture Collection (ATCC $\AA$ HTB38 $8^{\mathrm{TM}}$ ) was cultured in McCoy's 5A (Sigma, USA) culture medium supplemented with $10 \%$ fetal bovine serum (FBS) (Gibco, USA), 1\% penicillinstreptomycin and $1 \%$ amphotericin and maintained at $37^{\circ} \mathrm{C}$ in a humid atmosphere containing $5 \% \mathrm{CO}_{2}$. Passage of the cells was achieved every 3 days through trypsinization ( $0.25 \%$ trypsin (GIBCO)) and then the cells were treatment with or without or different concentration of CFL $(5,10,0 \mu \mathrm{g} / \mathrm{ml})$, respectively, for 24 hours.

\section{Apoptosis analysis}

HT-29 cells were cultured in a $24-$ well plate at a density of $2 \times 10^{5} /$ plate. The cells were treated with several concentrations of 5-fluorouracil (5-FU) $5 \mu \mathrm{g}$ and CFL (5, 10 and $20 \mu \mathrm{g} / \mathrm{ml}$ ) for $24 \mathrm{~h}$ and collected by trypsinization. The cells were washed with phosphate buffer saline (PBS). For each sample, $2.5 \mu \mathrm{g} / \mathrm{ml}$ Annexin-V-FITC and $50 \mu \mathrm{g} / \mathrm{ml}$ propidium iodide (PI) (Biolegend) were added to the cell suspension and incubated for $5 \mathrm{~min}$ at room temperature $\left(25^{\circ} \mathrm{C}\right)$ in the dark. Cell death by apoptosis was scored by quantifying the population of Annexin V-FITC-positive cells. Flow cytometry data were plotted and analyzed by Cell-Quest software (Becton Dickinson FACS Calibur).

\section{Cell cycle analysis}

HT-29 cells were cultured in a 24-well plate at a density of $2 \times 10^{5} /$ plate. The cells were treated with several concentrations of 5 -FU $5 \mu \mathrm{g}$ and CFL $(5,10$ and $20 \mu \mathrm{g} / \mathrm{ml})$ for 24 hours and collected by trypsinization. The cells were washed with PBS and then, suspended in $25 \mu \mathrm{g} / \mathrm{ml}$ propidium iodide (PI) (Biolegend) solution and incubated at $4^{\circ} \mathrm{C}$ in the dark for 25-30 minutes. The cell cycle percentage was measured by Flow cytometry and then analyzed by Cell-Quest software (Becton Dickinson FACS Calibur).

\section{Cell proliferation analysis}

HT-29 cells were cultured in a 24-well plate at a density of $2 \times 10^{5} /$ plate. The cells were treated with several concentrations of $5 \mu \mathrm{g} 5$-FU and CFL $(5,10$, and $20 \mu \mathrm{g} / \mathrm{ml})$ for 24 hours and collected by trypsinization. The cells were washed with PBS and then, labeled with bromodeoxyuridine (BrdU) conjugated fluorescein (FITC) for 30 minutes at $4^{\circ} \mathrm{C}$. The cell proliferation was measured by flow cytometry analyzed by Cell-Quest software (Becton Dickinson FACS Calibur).

\section{Cytotoxic assay}

HT-29 cells were cultured in a 96-well plate at a density of $1 \times 10^{3} /$ well. The cells were treated with $5 \mu \mathrm{g}$ of 5 -FU and different concentrations of CFL $(5,10$ and $20 \mu \mathrm{g} / \mathrm{ml})$ for 24 hours. The cells were treated with $20 \mu \mathrm{l}$ MTT (Sigma, USA) solution and followed with incubation at $37^{\circ} \mathrm{C}$ for 4 hours. Subsequently, 150 $\mu \mathrm{l}$ of solvent MTT was added and shaked the plate for 15 minutes. The quantity of formazan (presumably directly proportional to the number of viable cells) was measured by recording changes in absorbance at $630 \mathrm{~nm}$ using spectrophotometer. The inhibition concentration was calculated following the formula:

Inhibitory $\%=($ Control absorbance-control medium absorbance) - (Treatment absorbance-control medium absorbance $) /($ Control absorbance - control medium absorbance $)) \times$

$$
100 \%
$$

\section{Statistical analysis}

The results were analyzed by one-way ANOVA followed by Post Hoc Tukey test. Pearson correlation and regression test to determine the relationship between each group. Data were described as a mean \pm standard deviation. Statistical significance of a difference between groups, with $P<0.05$ being considered 
significant. Statistical analysis was performed with SPSS Version 11.0 statistic software package (SPSS Inc, Chicago IL, USA).

\section{RESULT AND DISCUSSION}

\section{Results}

Synergistically effect of $5 F U$ and coelomic fluid induced apoptosis

In our research, we evaluated the response of CFL and 5-FU combinations. We investigated that the apoptosis effect of cervical cancer HeLa cells in the combination of 5-FU and coelomic fluid on HT-29 cells using double staining method
FITC-conjugated annexin V and PI. The results of flow cytometry showed the percentage of apoptosis significantly increase on the combination of 5-FU and CFL $(P<0.05)$ followed by increasing concentrations of CF (Figure 1A and B). The administration of CFL at dose in group IV $(10 \mu \mathrm{g} / \mathrm{ml}), \mathrm{P}<0.001$; group V $(20 \mu \mathrm{g} / \mathrm{ml}), P<$ 0.001 increased the levels of apoptotic cell presentation compared single therapy group. These results suggested that combination of 5-FU and CFL had synergistically increased apoptosis in HT-29 cells. In this study, a combination of 5-FU with 10 and $20 \mu \mathrm{g} / \mathrm{ml}$ CFL able to suppress carcinogenesis by increasing the apoptosis of HT-29 cells. Therapy combination of 5-FU and different concentration of CFL $(5,10,20 \mu \mathrm{g} / \mathrm{ml})$ significantly enhances cell apoptosis $(P<0.05)$.
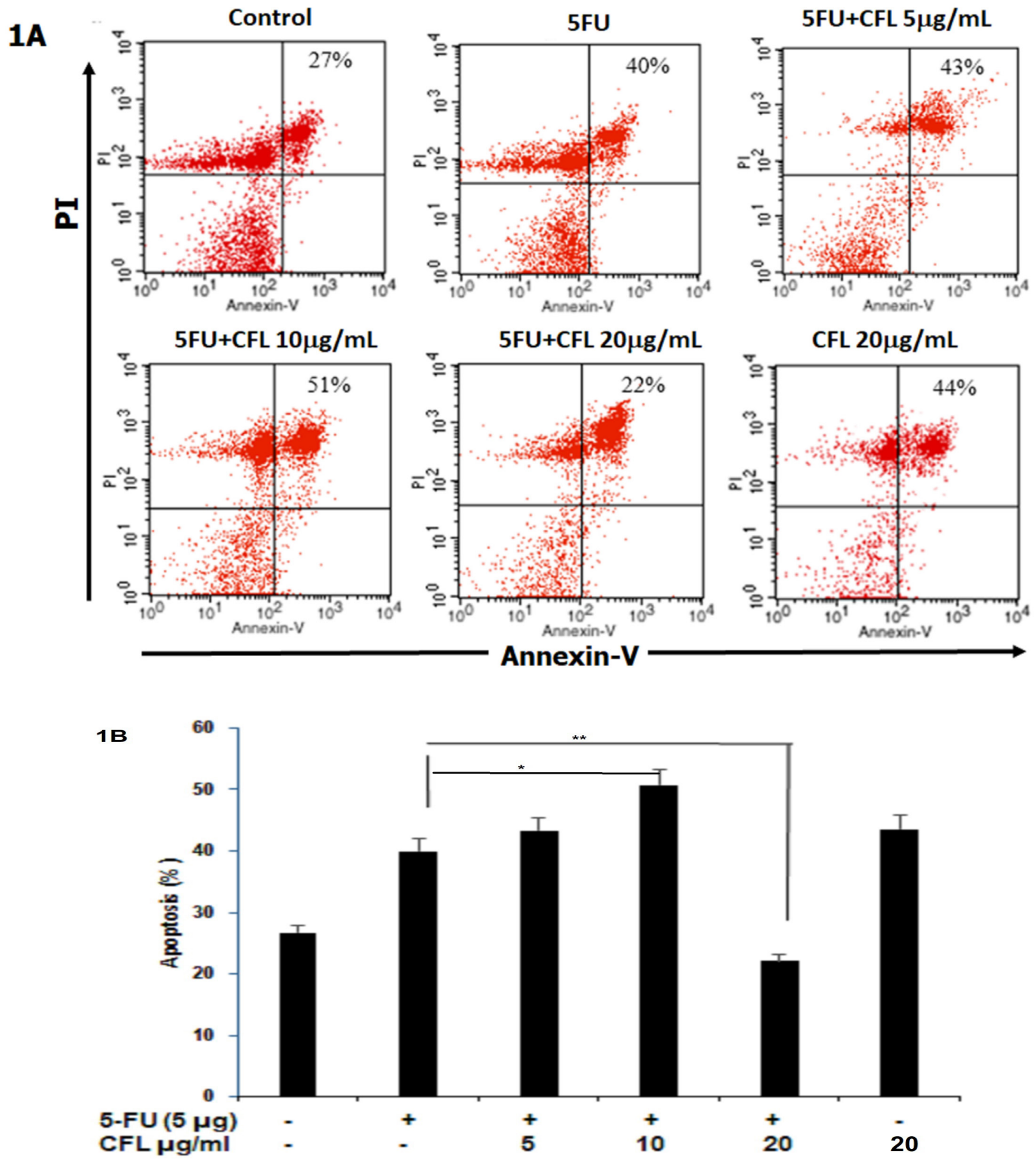

Fig. 1: The effect of 5-FU with or without coelomic fluid on the percentage of apoptosis. The effect of the combined 5-Fu and CFL to the apoptosis on HT-29 cells were treated with 5 -Fu with or without 5,10 , and $20 \mu \mathrm{g} / \mathrm{ml} \mathrm{CFL}$ were added for another 24 hours. (A) The percentage of apoptosis cells were analyzed using a FACS Calibur flow cytometer. Representative results of four replicates in each group are shown. (B) The combination of 5-Fu and CFL increased the percentage of apoptosis in HT-29 cells. Results shown are mean $\pm \mathrm{SD}$, with $\mathrm{n}=4$ replicates in each group. ${ }^{*} P<0.05,{ }^{*} P<0.001$ vversus 5 -FU only group. 

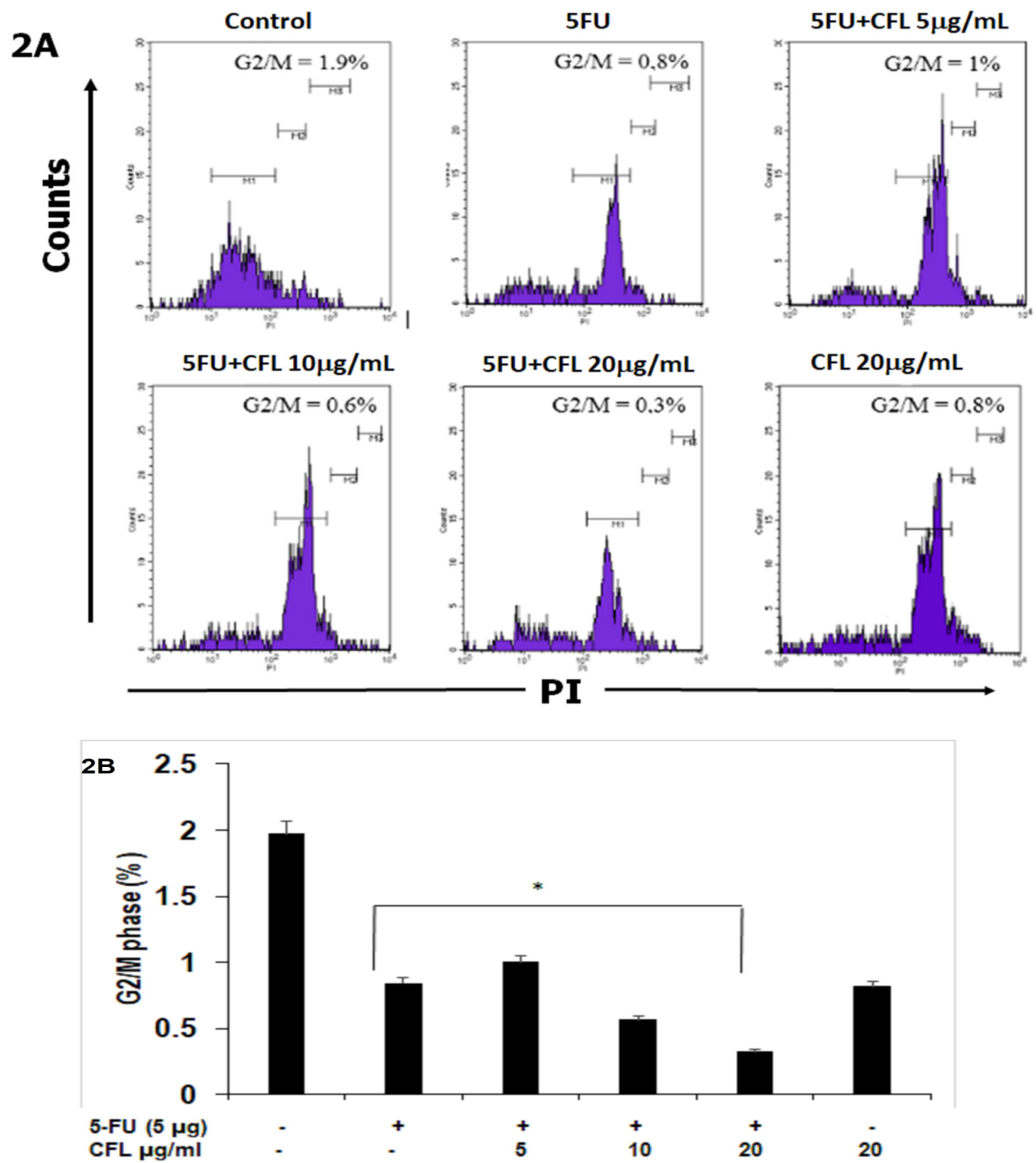

Fig. 2: Effects of 5-FU with or without coelomic fluid on the G2/M phase in HT-29 cells. HT-29 cells were treated with $5 \mu \mathrm{g} 5$-FU with or without CFL (5, 10, and $20 \mu \mathrm{g} / \mathrm{ml}$ ) were added for another 24 hours. (A) Percentages of G2/M phase in each histogram were shown inside the panels. (B). Numbers represent the percentages of G2/M phase in each histogram were shown. The percentage of G2/M phase decreases in all treatment groups compared with 5-FU only. Results shown are mean + $\mathrm{SD}$, with $n=4$ replicates in each group. $* P<0.05, * * P<0.001$ versus 5 -FU group.

The combined effect of 5-FU and coelomic fluid inhibits the G2 phase of the cell cycle

To know the combination effect of 5-FU and CFL on cell cycle progression at $\mathrm{G} 2 / \mathrm{M}$ phase involved in this study, we determined the percentage of $\mathrm{G} 2 / \mathrm{M}$ phase. The histograms showed the percentage of the cell cycle in HT-29 cells was treated with 5-FU $5 \mu \mathrm{g}$ and CFL $(5,10$, and $20 \mu \mathrm{g} / \mathrm{ml})$ for 24 hours. The G2/M phase of the cell cycle was represented on the histogram as M3 (Figure 2A). The effect of combination therapy shown slightly reduce the percentage of $G 2 / \mathrm{M}$ phase in the cell cycle (Figure $2 \mathrm{~B}$ ). The $\mathrm{G} 2 / \mathrm{M}$ phase in combination groups decreased $66.5 \%$ compared with single therapy group. These results indicated the percentage of G2/M phase slightly increased in CFL combinations groups compared to the single therapy group.

The combination therapy of 5-FU and CFL inhibit proliferation in HT-29 cells

HT-29 cells were treated using the single 5-FU with or without CFL in various concentrations $(5,10$, and $20 \mu \mathrm{g} / \mathrm{ml})$, proliferation was observed by anti-BrdU staining using flow cytometry. The proliferation was represented on the histogram 
as M1 (Figure 3A). HT-29 cells have undergone proliferation as induced by the combination of 5-FU and $20 \mu \mathrm{g} / \mathrm{ml} \mathrm{CFL.} \mathrm{Our}$ data presented the percentage of cell proliferation significantly decreased $(P<0.05)$ in $20 \mu \mathrm{g} / \mathrm{ml}$ concentration (Figure 3B). In this study, a combination of 5-FU and CFL suppressed carcinogenesis by reducing the proliferation of HT-29 cells.
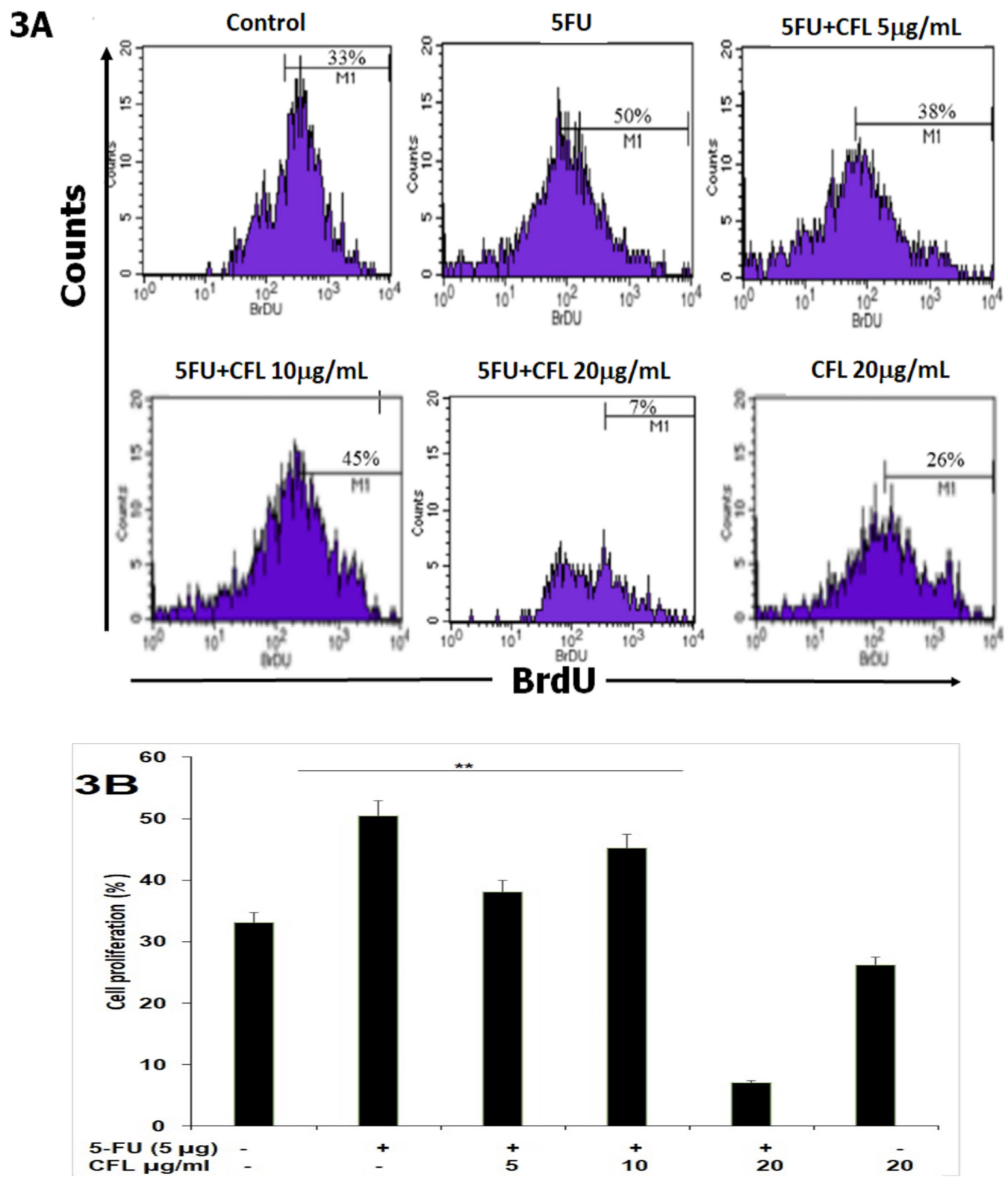

Fig. 3: The inhibitory proliferation of 5-FU with or without coelomic fluid on the growth of HT-29 cells. (A). The proliferation of HT-29 cells following 24 hours treatment of 5-FU with or without CFL $(5,10$, and $20 \mu \mathrm{g} / \mathrm{ml})$. The percentage of BrDU cells were analyzed using a FACS Calibur flow cytometer (BD Biosciences). Representative results of four replicates in each group are shown (B). Numbers represent the percentages of BrDU in each histogram are shown. Results shown are mean $\pm \mathrm{SD}$, with $n=4$ replicates in each group. ${ }^{*} P<0.05,{ }^{*} P<0.001$ versus 5 -FU only group.

The combination effect of 5-FU and CFL on cytotoxic effect

Combination therapy of 5-FU and CFL able to kill HT-29 cells effectively. The cytotoxic effect was represented on the histograms. The combination of 5-FU and CFL with various concentrations $(5,10$, and $20 \mu \mathrm{g} / \mathrm{ml})$ could kill HT-29 cells by $13 \%, 29 \%$, and $87 \%$, respectively (Figure 4). CFL enhances the cytotoxicity effect of 5-FU in inhibiting the growth of HT-29 cells. $(p<0.05)$. These results suggested that combination of $5-\mathrm{FU}$ and
CFL inhibited cell growth.

\section{Discussion}

Colon cancer is caused by many factors, including chronic inflammatory disease, environmental effects, and lifestyle (Endharti et al., 2016, Endharti et al., 2017a, Endharti et al., 2017b). Currently, the most widely used chemotherapy drug is 5-Fluorouracil (5-FU) (Chua et al., 2011). 5-FU is frequently 
used in in vitro research using colon cancer cell line HT-29 for developing antiretroviral drugs against anti-apoptotic activity (Qiu et al., 2015).

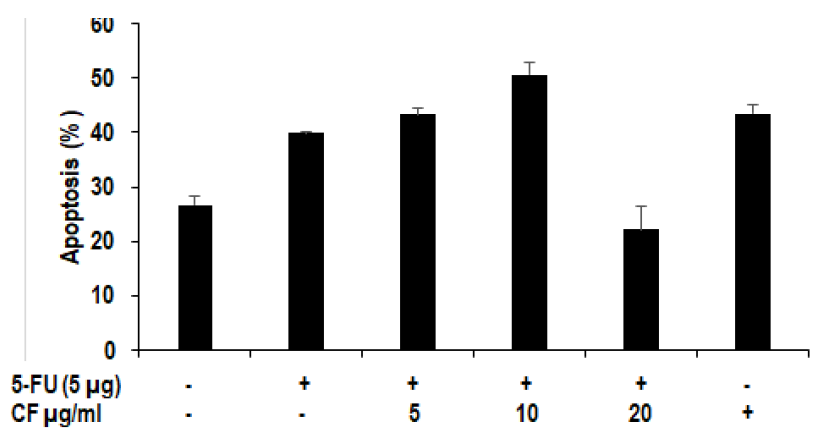

Fig. 4: The cytotoxic effects of the combination of 5-FU and coelomic fluid against HT-29 cells. The cytotoxic effect of 5-FU with or without different concentration of coelomic fluid $(5,10$, and $20 \mu \mathrm{g} / \mathrm{ml})$ on HT-29 cells determined by MTT assay. Values represent mean $\pm \mathrm{SD}$ with triplicate determinations for $50 \%$ inhibitory concentration (IC50). Data values represent (mean \pm SD) that obtained in triplicate assays from four independent experiments $\left({ }^{*} p<0.05\right.$ or $* * p<0.05$ compared with 5-FU as control)

CFL of earthworms reported have the function of cell proliferation and apoptosis in HeLa cells. (Zhang et al., 2011). CFL contains coelomic cytolytic factor-1 (CCF-1) and lysenin, which have known cytotoxic effects on in vitro cancer cells (Chen et al., 2007; Kobayashi et al., 2004). CCF-1 acts similar to tumor necrosis factor alpha (TNF- $\alpha$ ), which binds the tumor necrosis factor receptor 1 (TNFR1) to activate the proliferative pathway via mitogen-activated protein kinase (MAPK) (Mancikova, 2011). It has been suggested that CFL containing CCF-1, analogous to TNF- $\alpha$, binds TNFR1 and thereby inhibits the cell proliferative mechanism (Horssen et al., 2006). Lysenin, through ceramide-sphingomyelin pathways, is essential for cell apoptosis, proliferation, and cell cycle inhibition (De Colibus et al., 2012).

Our study has confirmed that CFL treatment with or without combination drug chemotherapy has an effect on the colon cancer cell line HT-29. CFL was used to propose as a way to minimize doses of 5-FU as a chemotherapy agent and thus minimize resistance to chemotherapy, which contributes to most cancerrelated deaths. In addition, with increasing of CFL concentration, cell cycle changed markedly including the percentage of G2/M phase decreased, but not a significant difference between groups. Our study found that the combination therapy able to enhance the percentage of apoptosis. The apoptosis was associated with DNA damage that stops DNA replication (Kracikova et al., 2013) and G2/M checkpoint prevents cells from undergoing mitosis before they have a chance to repair damaged DNA after replication (Medema and Macůrek, 2011).

Lumbricus rubellus has a cytotoxic effect through CFL containing lysenin protein (Kobayashi et al., 2004; Endharti et al., 2018). Lysenin activates caspase 9 to signal the mitochondrial pathway to promote apoptosis (Chalfant et al., 2002; Ghosh et al., 2007).

The combination of 5-FU and CFL in a dosagedependent manner is simultaneously capable of increasing apoptosis with inhibiting cell proliferation, capable of increasing cytotoxic effects but does not alter the cell cycle. The maximum dose of coelomic fluid that increased cytotoxic effects was $5 \mu \mathrm{g} /$ $\mathrm{ml}$, that increased cell apoptosis was $10 \mu \mathrm{g} / \mathrm{ml}$ and that decreased cell proliferation was $20 \mu \mathrm{g} / \mathrm{ml}$.

\section{CONCLUSION}

In conclusion, the study showed that the combination of 5-FU and coelomic fluid able to enhance the percentage of apoptosis cells, cytotoxic effect and inhibit cell proliferation of HT-29 cells. Our results showed that CFL offers a promising anticancer candidate. These findings highlight the new therapeutic concept which combines 5-FU chemotherapy agents and coelomic in the treatment of colon cancer.

\section{ACKNOWLEDGMENTS}

We would like to thank Directorate General of Higher Education, Ministry of National Education and Culture of Republic Indonesia for the provided grant for this research. We gratefully acknowledge Heni Endrawati, SSi, Wahyudha Ngatiril Lady, SSi and Bunga Prihardina, SSi for technical assistance.

\section{CONFLICT OF INTERESTS}

The authors declare that there is no conflict of interest regarding the publication of this paper.

\section{REFERENCES}

Niederhuber JE, Armitage JO, Doroshow JH, Tepper JE. 2014 Abeloff's Clinical Oncology Fifth edition. Philadelphia, PA 19103-2899.

Au-Yeung KK, Ko JK. Novel herbal flavonoids promote apoptosis but differentially induce cell cycle arrest in human colon cancer cell. Investigational New Drugs, 2010; 28(1):1-13.

Chalfant CE, Rathman K, Pinkerman RL, Wood RE, Obeid LM, Ogretmen B, Hannun YA. De novo ceramide regulates the alternative splicing of caspase 9 and Bcl-x in A549 lung adenocarcinoma cells. Dependence on protein phosphatase-1. J Biol Chem, 2002; 277:1258712595.

Chen H, Takahashi S, Imamura M, Okutani E, Zhang Z, Chayama K, Chen BA. Earthworm fibrinolytic enzyme: anti-tumor activity on human hepatoma cells in vitro and in vivo. Chin Med J, 2007; 120:898-904.

Chua W, Kho PS, Moore MM, Charles KA, Clarke SJ. Clinical, laboratory and molecular factors predicting chemotherapy efficacy and toxicity in colorectal cancer. Crit Rev Oncol Hematol, 2011; 79(3):224-250.

Ciccolini J, Gross E, Dahan L, Lacarelle B, Mercier C. Routine dihydropyrimidine dehydrogenase testing for anticipating 5-fluorouracilrelated severe toxicities hype or hope? Clin Colorectal Cancer, 2010; 9(4):24-8

Cooper EL, Balamurugan M, Huang CY, Tsao CR, Heredia J, Tommaseo-Ponzetta M, Paoletti MG. Earthworms dilong: Ancient, inexpensive, noncontroversial models my help clarify approaches to integrated medicine emphasizing neuroimmuno systems. Evid Based Complement Alternat Med, 2012; 2012:1-11.

De Colibus L, Sonnen AFP, Morris KJ, Siebert CA, Abrusci P, Plitzko J, Hodnik V, Leippe M, Volpi E, Anderluh G, Gilbert RJ. Structures of Lysenin Reveal a Shared Evolutionary Origin for Pore-Forming Proteins and its Mode of Sphingomyelin Recognition. Structure, 2012; 20(9):1498507.

Dinesh MS, Sridhar S, Chandana PG, Pai V, Geetha KS, Hegdge RN. Anticancer Potentials of Peptides of Coelomic Fluid of Earthworm Eudrilus eugeniae. Biotech Res Asia, 2013; 10(2):601-606.

Endharti AT, Adisti W, Anik L, Eviana N, Sofy P. Dendrophthoe pentandra (L.) Miq Extract Effectively Inhibits Inflammation, Proliferation and Induces p53 Expression. BMC, 2016; 16(374):1-8. 
Endharti AT, Baskoro AD, Norahmawati E, Therapeutic effect of soluble worm protein acting as immune regulatory on colitis. Asian Pac $\mathrm{J}$ Trop Biomed, 2017a; 7(1):70-77.

Endharti AT and Permana. S. Extract from mango mistletoes Dendrophthoe pentandra ameliorates TNBS induced colitis by regulating $\mathrm{CD} 4+\mathrm{T}$ cells in mesenteric lymph nodes. BMC Complementary and Alternative Medicine, 2017b; 17:468.

Endharti AT, Permana S. T-Bet Is Dependent on Stat-4 Inhibiting Acute Colitis but Not Stat-1 Using L4 Somatic Antigen of Heligmosomoides polygyrus. The Scientific World Journal, 2018; 2018:1-10.

Ferlay J, Shin HR, Bray F, Forman D, Mathers C, Parkin DM. Estimates of worldwide burden of cancer in 2008: GLOBOCAN 2008. Int J Cancer, 2010; 127(12):2893-2917.

Ferlay J, Soerjomataram I, Dikshit R, Eser S, Mathers C, Rebelo M, Parkin DM, Forman D, Bray F. Cancer incidence and mortality worldwide: Sources, methods and major patterns in GLOBOCAN 2012. Int J Cancer, 2015; 136(5):359-386.

Ghosh N, Patel N, Jiang K, Watson JE, Cheng J, Chalfant CE, Cooper DR. Ceramide-activated protein phosphatase involvement in insulin resistance via Akt, serine/arginine-rich protein 40, and ribonucleic acid splicing in L6 skeletal muscle cells. Endocrinology, 2007; 148:1359-1366.

Horssen RV, Timo LM, Alexander MM. TNF- $\alpha$ in Cancer Treatment: Molecular Insights, Antitumor Effects and Clinical Utility. The Oncologist, 2006; 11:394-408.

Jaabir MMS, Shamsheerali L, Yasar MMD, Kumar SS Evaluation of the cell-free coelomic fluid of the earthworm Eudrilus euginiae to induce apoptosis in SiHa cell line. Journal of Pharmacy Research, 2011; $4(10): 3417-3420$

Kobayashi H, Ohta N, Umeda M. Biology of Lysenin, a Protein in the Coelomic Fluid of the Earthworm Eisenia foetida. Japan. International Review of Cytology, 2004; 236:45-99.

Kracikova M, Akiri G, George A, Sachidanandam R, Aaronson SA. A threshold mechanism mediates $\mathrm{p} 53$ cell fate decision between growth arrest and apoptosis. Cell Death Differ, 2013, 20:576-588.

Kraveka JM, Li L, Bielawski J, Obeid LM, Ogretmen B. Involvement of endogenous ceramide in the inhibition of telomerase activity and induction of morphologic differentiation in response to alltransretinoic acid in human neuroblastoma cells. Arch Biochem Biophys, 2003; 419:110-119.

Mancikova V. 2011. Molecular Characterization of Selected Defense Factors in Lumbricidae. Prague; Charles University. Thesis.

Medema RH, Macůrek L. Checkpoint recovery in cells: how a molecular understanding can help in the fight against cancer. F1000 Biology Reports, 2011; 3:10.
Mishra J, Dromund J, Quazi SH, Karanki SS, Shaw JJ, Chen B, Kumar N. Prospective of Colon Cancer Treatments and Scope for Combinatorial Approach to Enhanced Cancer Cell Apoptosis. Crit Rev Oncol Hematol, 2013; 86(3):232-250.

Ogretmen B, Schady D, Usta J, Wood R, Kraveka JM, Luberto C, Birbes H, Hannun YA, Obeid LM. Role of ceramide in mediating the inhibition of telomerase activity in A549 human lung adenocarcinoma cells. J Biol Chem, 2001; 276:24901-24910.

Qiu T, Xiang X, Lei W, Hao C, Zhang L, Feng M, Yu F, Li J, Xiong J. Establishment and biological characterization of 5-fluorouracilresistant human colon cancer HT-29/5-FU cell line. Xi Bao Yu Fen Zi Mian Yi Xue Za Zhi, 2015; 31(3):328-32.

Redondo-Blanco S, Fernández J, Gutiérrez-del-Río I, Villar CJ, Lombó F. New Insights toward Colorectal Cancer Chemotherapy Using Natural Bioactive Compounds. Front Pharmacol, 2017; 8: 109.

Vidya N, Dinesh MS, Ananda S, Radha DK. Cytotoxic Potential of Eudrilus eugeniae coelomcyte culture supernatant against tumor cells. International Journal of Scientific and Research Publications, 2016; 6(8):2250-3153.

Watanabe T, Itabashi M, Shimada Y, Tanaka S, Ito Y, Ajioka Y, Hamaguchi T, Hyodo I, Igarashi M, Ishida H, Ishihara S, Ishiguro M, Kanemitsu Y, Kokudo N, Muro K, Ochiai A, Oguchi M, Ohkura Y, Saito Y, Sakai Y, Ueno H, Yoshino T, Boku N, Fujimori T, Koinuma N, Morita T, Nishimura G, Sakata Y, Takahashi K, Tsuruta O, Yamaguchi T, Yoshida M, Yamaguchi N, Kotake K, Sugihara K; Japanese Society for Cancer of the Colon and Rectum. Japanese Society for Cancer of the Colon and Rectum (JSCCR) Guidelines 2014 for treatment of colorectal cancer. Int J Clin Oncol, 2015; 20:207-239.

Zhang H, Yan-Hong W, Hong-Wei C, Li-Jun P, Yu-Dong C. Purification of a protein from coelomic fluid of the earthworm Eisenia foetida and evaluation of its hemolytic, antibacterial, and antitumor activities. Pharmaceutical Biology, 2011; 49(3):269-275.

How to cite this article:

Permana S, Pearlindah, Sholihah Z, Iskandar A, Susanti H, Endharti AT. Cytotoxic effects and anti-proliferative cancer activity of coelomic fluid from Lumbricus rubellus promotes apoptosis and reduces G2/M phase progression in HT-29 cells. J App Pharm Sci, 2018; 8(11): 028-034. 